\title{
American Reference Libraries in the Postwar Era
}

Mr. Kellar, director of the McCormick Historical Association, read this paper at the meeting of the Association of College and Reference Libraries, June 23, 1942.

T THE MIDST of a world upheaval which 1 affects the life of every individual in the nation it may seem to certain persons a futile procedure to attempt to discern the shape of things to come, but I do not think that this is really so. If the longrange objective of the librarian is to promote availability of knowledge for the good of a continuing civilization, we must keep our feet on the ground, look into the future, and endeavor to ascertain how we may play our part in the days when peace will again descend upon the world.

The American reference library has long constituted one of the chief pillars of culture in our civilization. For the most part the content of these institutions represents the accumulations of time. Often starting with a small nucleus of material, holdings have steadily grown over a period of years to reach their present status. In a few instances, such as Huntington and Duke and Clements, they have sprung like Aphrodite out of the sea, full-grown or almost full-grown, within a comparatively brief space of time. Nearly all of them have come into adequate being within the past half century. Since 1900 housing has consistently limped behind ex- pansion and although many new and sometimes splendid library buildings have been constructed in this country, particularly in recent years, acquisitions of material have increased so rapidly that a number of the newer structures have little room left for future requirements.

An interesting aspect of the American reference library has been the point of view directing its development. Prior to 1929, with few exceptions, the prevailing laissez-faire philosophy of the general public, confirmed in part by the results of the First World War, animated the activities of librarians and sponsors. Each institution was prone to select the fields in which it was interested without regard to the total picture of library acquisitions and joyously to compete with every other library for anything that it wanted. The possible wisdom of such procedure or the results over a period of time were largely unquestioned. Under these conditions, in the usual American fashion, the race was won by the most active institutions and those with the largest funds available for acquiring additional material.

The economic depression, which began in 1929 and continued well into the nineteen-thirties, caused a rude awakening in society, which was reflected in the library world. Privately endowed institutions soon found the value of their securities lessened and interest rates beginning to 
decline. The net result was less income. Public institutions suffered in similar fashion through difficulties in tax collections in municipalities and both inability and unwillingness of state and national legislatures to provide adequate funds for library activities. The situation was made more serious by a large increase of consumer demand upon institutions. The unemployed had leisure for more reading.

\section{Federal Assistance}

However, the cloud was not without its silver lining. Federal assistance gradually, came to the aid of a harassed society, including its institutions. A number of new libraries were built with government funds, and the National Youth Administration, the Federal Writers Project, and the Historical Records Survey offered clerical and sometimes skilled assistance to librarians. The latter were frequently skeptical of such aid at the outset and embraced the opportunity presented with reluctance but the majority of the profession learned in time to make wise use of white-collar relief labor. As a result many needed activities in individual libraries were carried on that otherwise would have had to cease and others were undertaken on a scale which hitherto had not been contemplated. In addition larger projects such as the American Imprints Inventory, surveys of Federal, state, municipal, and county archives, church records, manuscript collections, and like activities, inaugurated by the Historical Records Survey, proved of direct interest to librarians. Equally important was the further development of union catalogs and bibliographical enterprises, the preparation of guides and indexes to newspaper holdings, and the filming of newspaper files for pur- poses of preservation and to provide needed space. The discovery that it was possible to make widespread use of white-collar relief labor was a fact of tremendous significance and nowhere was this more important than in the library world. To the vision of the late Robert C. Binkley, who foresaw these things and worked out practical methods of applying them, librarians are everywhere greatly indebted.

Most important in the nineteen-thirties and directly connected with the activities mentioned above, was the gradual shift in point of view from the individualistic attitude of the previous decade to a more social approach with respect to library activities. Public approval and financial support of institutions began to be contingent more and more upon the service they rendered to society. Individualistic interest or ambition as expressed in an institution was not enough to any longer justify reason of being. The trend has been definitely established and is likely to go further.

\section{Effect of War}

The outbreak of the Second World War in September 1939 and our own entrance in December I94I have further affected reference libraries in various ways. Privately endowed institutions, instead of being able to look forward under happier economic conditions to a rise in the present low interest rates upon their securities and to an increased income, are faced with what is apparently a continuing period of prevailing and even lower rates of interest. The present heavy taxation, and there seems no prospect of relief in this direction, is drastically reducing the amount of funds normally available for gifts. Public institutions in submitting 
budgets for legislative enactment recently have almost always found them curtailed before they were given final approval. Also staffs are reduced because of entrance of members into the armed forces or undertaking other defense activities, making it difficult to continue current services.

One important phase has been an increasing demand upon libraries in many parts of the country to supply technical information required for research, as well as other types of reading matter, to individuals living in areas where defense projects are being rapidly developed. In a number of institutions so voluminous have been the requests that it has been found impossible to meet current needs in a satisfactory manner. Present facilities are insufficient and funds are not available to expand them. This has led to a renewal of attempts to obtain Federal legislation authorizing the creation of regional depositories. It is quite possible that one result of the emergency will be the establishment of such libraries, furnished with free copies of copyright publications. It is to be hoped, however, that instead of making these regional libraries branches of the Library of Congress, as many of the bills propose, that Congress, if it does act, will select some existing institution in each region, best suited for the purpose, and make it the regional depository.

\section{Technical vs. Humanities Libraries}

Also to be noted is the possible danger that the present emphasis upon the practical importance of libraries supplying technical data may lead to legislative support of these institutions at the expense of reference libraries devoted to the humanities. Our culture to be lasting requires balance between the various phases of intellectual interest and activity. We need to encourage things of the spirit as well as to furnish information about chemical elements.

Signs have not been wanting in the past few years that many librarians have become dissatisfied with our hitherto individualistic methods of developing reference libraries. It grows obvious with time that no one library, no matter how large its resources, can hope to acquire all of the material it should have in a number of fields. To achieve subject completeness, even in a single field, with one possible exception, that of the Surgeon General's Library, has so far proved beyond our capacity. The increased cost of competition, which recently has often had to be met with lowered income, has finally driven the lesson home. One answer is adoption through library cooperation of a planned system of allocation in acquisitions, but before this can be worked out and applied, we must know what materials for research have been assembled in this country and where they are located. As an aid in throwing light upon this last subject various undertakings have been projected and carried out. The compilation, Resources of Southern Libraries, ${ }^{1}$ afforded valuable information concerning institutions in the South. The Guide to Library Facilities for National Defense, ${ }^{2}$ the annual reports on Notable Materials Added to American Libraries, ${ }^{3}$ the publication of the first volume of Special $L i$ brary Resources, ${ }^{4}$ the manuscript, imprint,

\footnotetext{
1 Downs, Robert B., ed. Resources of Southern Libraries: A Survey of Facilities for Research. Chi. cago, 1938.

2 Cannon, Carl L., ed. Guide to Library Facilities for National Defense. Chicago, 1940.

${ }^{3}$ Downs, Robert B., ed. Notable Materials Added to American Libraries, 1938-4I. Reprinted from Library Quarterly, I0:I57-91, April 1940; I I:257-

301, July 1941 ; 12:175-220, April 1942. sources. Vol. I. New York, I941.
} 
church records, and other surveys of the Historical Records Survey, and the development of union catalogs, to mention only a few, offer information of pertinence. The Conference on Library Specialization, sponsored by the American Library Association Board on Resources of American Libraries, ${ }^{5}$ held at Columbia University in May $194 \mathrm{I}$ and the activities of the Experimental Division of Library Cooperation indicate a clear interest in planned allocation.

\section{Future of Reference Libraries}

What is the future of American reference libraries in the postwar period? If the Axis powers should win the answer is relatively simple, elimination of certain libraries, consolidation of others, and possible creation of a few new institutions. Throughout there will be thorough regimentation and subordination of collections and activities in the interests of propaganda for the so-called national state or the Japanese Empire, as the case may be.

Now turn to a more pleasant prospect, an era in which a lasting peace will follow a final victory achieved by the United Nations.

\section{Leadership}

Leadership among American reference libraries will then be achieved by those institutions presided over by far-seeing librarians and governing boards who will concentrate holdings in a few selected fields or subfields of knowledge and endeavor to render adequate service for research or general information in their specialties.

- Downs, Robert B., ed. Library Specialization, Proceedings of an Informal Conference Called by the A.L.A. Board on Resources of American braries, May I3-I4, I94I. Chicago, 1941.

\section{Financial Support}

At present the future for privately endowed institutions seems uncertain because their securities will continue to bear low interest rates and they will have possible difficulty in acquiring additional funds. Such libraries doubtless will continue to exist and to render valuable service but they may be curtailed in activities and expansion by considerations of this kind. Procuring public funds in some manner or consolidation with public institutions may provide a more practical future for certain of these libraries. Reference libraries connected with universities will possibly be aided by increase of student fees, but advance in this direction is probably limited. In general, if public institutions undertake responsibility for adequate servicing in their field or the area of their activity, whether this be a community, a state, a region, or the nation, they will be aided by governmental funds and should enlarge and expand their facilities to their logical limits.

\section{Library Cooperation}

Inasmuch as it is now generally conceded that no reference library can hope to reach its fullest development unaided and alone in the library world, participation in practical library cooperation, wherever possible, would seem to be a fundamental procedure for such institutions in the postwar period. The completion of various library cooperation projects will not only aid the operation of individual institutions but strengthen the library system of the country as a whole so that it will function in a national sense.

White-Collar Relief Labor

Economic conditions in the postwar era 
undoubtedly will make relief labor, supported by government funds, again available in large measure. Reference libraries should make definite plans to carry out numerous activities with assistance of this type.

\section{Acquisition, Control, and Mobility of Ma- terials}

The completion of the National Union Catalog in the Library of Congress, which at present is about half done, will prove of great service to all reference libraries and now and in the future they should help the expansion of this compilation designed to give the location of all important books held in depositories in this country. Assistance to this project can be rendered in several ways. Copies or duplicates of catalog cards for books processed by each reference library should be forwarded regularly to the National Union Catalog. Duplicates of order lists for Library of Congress catalog cards should be sent to the Union Catalog in order to allow the latter to show locations in various depositories. One or more reference libraries in each state should assume the responsibility for editing and publishing checklists of American imprints for the state based upon the original field notes of the American Imprints Inventory. The original files are now in the custody of the Library of Congress, deposited at the State Historical Society of Wisconsin at Madison. Fifty state checklists will have been published by July 1942 but more than two hundred others are required to exhaust the titles in the national file. In general the entries in the inventory cover all publications up to and including 1876 but in a few instances they go forward to and including 1890 .
The proposed reproduction by offset printing of the Depository Catalog of the Library of Congress is an excellent project and these sets will be widely purchased and used. Similarly when the National Union Catalog is completed, it should also be copied and made available in individual institutions throughout the country. Because of the bulk of this compilation it is probable that microfilm or microprint would be better copying mediums than offset printing.

\section{State and Regional Union Catalogs}

Reference libraries should also cooperate in the development of existing community, state, and regional union catalogs. In certain instances this will involve abandonment of existing jealousies between institutions and arrival by joint decision among the libraries of an area as to which union catalog to sponsor and by what means. Continued financial support of union catalogs, other than that at the Library of Congress, may require a division of the cost of maintenance among a number of institutions in an area, such as has been recently worked out for the Philadelphia Bibliographical Center and Union Library Catalogue. Where necessary this should be done. If local or other union catalogs are needed but do not exist, by common agreement among institutions they should be created. Reference libraries should assist custodians of local, state, and regional catalogs in sending copies of their holdings to the National Union Catalog for the purpose of adding titles to that compilation.

To create want lists of materials which should be acquired, these libraries should cooperate in setting up projects to examine the records of the American Imprints In- 
ventory, American and foreign dealers' and publishers' lists, American and foreign copyright records, the United States Cata$\log$, films of foreign catalogs and bibliographies, and subsequently check all of these against union catalogs. Learned societies should appoint committees to obtain from scholars and other research workers lists of printed and manuscript materials in their fields located in for eign countries, which should be secured and placed in depositories in the United States. An example of a list of this type would be the one compiled from data submitted by members of the American Historical Association, subsequently used as the basis of preparing lists of materials to be microfilmed in England, by the Committee on Microcopying Materials for Research of the American Council of Learned Societies. Undertakings of this nature would result in the production of local, state, and regional want lists, which in aggregate would make possible a national program of acquisition of materials needed for research.

\section{Union Lists}

Libraries should also make use of the new edition of the Union List of Serials for the purpose of compiling want lists of periodicals. On the basis of holdings given in the Union List, agreement might be reached with respect to assembling complete runs of important publications in designated localities. The value of the Union List of Serials would be increased if the scope of coverage were enlarged in future editions. Special libraries might interest themselves in the preparation of a union list of special periodicals which could serve as a foundation upon which to build want lists of such publications. A union list of foreign periodicals in this country should be prepared and this in turn could be used to provide want lists of publications desired by institutions. In similar fashion the Union List of Newspapers might be employed to produce want lists of newspapers. Libraries in various states should undertake the responsibility of compiling and publishing state lists of newspapers such as Texas Newspapers 18131939, recently prepared by the San Jacinto Museum of History Association.

The document field is a fruitful one for the assembly of union lists of material in the United States relating to this and to foreign countries. These lists should supplement the partial compilations that are already in existence.

Reference libraries in the postwar period should give attention to the preparation and publication of subject bibliographies. Institutions which possess especially good holdings in certain subfields should undertake such enterprises with a view to the eventual completion of subject coverage. Reproduction of a number of the divisions of the subject catalog of the New York Public Library by some low-cost method of copying, such as microprint, and wide distribution of these records, would prove stimulating to the production of subject bibliographies by American libraries and would provide additional material for want lists. An outstanding example of the possibilities of subject bibliography is the Bibliography of the History of the Invention of Printing, showing world locations, compiled by the Illinois Division of the Work Projects Administration under the direction of Douglas C. McMurtrie. Only about ro per cent of the titles listed can be found in any one library in the United States. 


\section{Coordinated Purchasing}

Some plan of coordinated purchasing upon a national scale, particularly with relation to the acquiring of foreign books, should be adopted and carried out by reference libraries. The object would be to make certain that at least one copy of infrequently-used books could be found somewhere in this country; those more frequently used would be placed in a number of strategically located centers; and copies of those constantly used would be obtained by all important reference libraries. Plans for the coordinated purchasing of books in regional areas, such as those now under way in the Denver Bibliographical Center and the Union Cata$\log$ of the Northwest, should be adopted in other regions when proved of continuing value. Systems of coordinated purchasing in states, such as that of the Oregon state system of higher education, merit study.

Important sources of acquisition are the historical and cultural source materials, both manuscript and printed, located in English depositories now being copied on microfilm and transferred to the Library of Congress, where they will be made available on payment of cost plus a reasonable service charge. This program, which is jointly sponsored by the American Council of Learned Societies and the $\mathrm{Li}$ brary of Congress and financed by the Rockefeller Foundation has been under way since January 194I. Millions of pages of material have been selected for copying and if the program is confined to England only, much new and valuable data will be made available to American institutions and scholars. If and when this program should be extended to cover other countries, the results will be even more worth while.

\section{Duplicate Volumes}

The task of redistributing and placing in circulation the large number of duplicate volumes now housed in individual institutions should be considered seriously. This material, which at present is not available in many places where it would be wanted if its existence were known, is frequently a burden to the holding institution. Creation of central agencies in localities, states, regions, and for the country as a whole, which would permit of an approach to this question in a national sense, would prove of great service. An essential first step would be the preparation of duplicate lists by members of the staff of individual libraries or by trained professionals assigned by an agency for the purpose. Subsequently, lists should be circulated in localities, states, and regions until national coverage of institutions had been achieved. Record of disposal of material in a library should be sent by the institution to the appropriate central agency of its area. The possibilities of widespread redistribution by gift, sale, exchange, or loan is suggested in the list of duplicates in the St. Louis Public Library recently compiled by Leonard Balz, of that institution, at the request of the Experimental Division of Library Cooperation. This impressive compilation, comprising approximately eighty thousand volumes and fifteen thousand scores of music, is only one example among many in other institutions.

Reference libraries should adopt a more liberal practice regarding exchange or long-term loan of original records held by them but which do not relate to their particular fields of interest. Included under this head would be rare single pieces, such as the Benjamin Franklin items which 
were formerly in the possession of the Minnesota Historical Society, or an extensive collection of material assembled in an institution, which through interruption of sponsorship for one reason or another has become in every sense a "dead collection." Unused in present depositories, data of this kind would be of value if placed in other institutions.

\section{Restriction on Gifts}

There is a noticeable trend among reference libraries to exercise definite restriction upon gifts in the interest of the receiving institution. Fully carried out, this would mean that libraries would generally adopt policies of refusing to accept material not in their particular sphere of interest and similarly that they would achieve complete authority with respect to the disposal of duplicates.

In the postwar period interlibrary lending, in all probability, will be carried on to a much greater extent than at the present time as reference libraries more and more accept the principle of servicing certain areas for the particular fields in which they specialize. The practice of charging moderate fees to cover costs of wrapping, express, postage, and insurance is likely to be widely recognized and adopted. Longterm loans will be more frequently made, both for definite and indefinite periods. It is probable that rental fees will be charged for the loan of large bodies of material. Protection against wear and tear upon original items will be assured through widespread use of microfilm and other types of copies for loan purposes.

Acquisition of new materials and mobility of all types of records will be greatly enhanced by use of various copying methods, such as microfilm and microprint.
Libraries in various parts of the country will be better serviced than at present by the extension of the use of existing film laboratories and the creation of others to take care of certain local requirements. A national agency will probably be established to furnish information to libraries concerning the latest copying methods, their application, value, and cost, and to promote standards of copying work.

\section{Warehouses}

The importance of warehouses for individual libraries and also for a number of institutions in an area will be more widely appreciated and the idea generally applied. Certain of these warehouses will undoubtedly become centers for bibliographical activities, coordinated purchasing, information, etc., taking over functions that in other areas very possibly will be carried on by union catalog centers.

In the postwar period reference libraries should make definite progress towards planned specialization. Fields of knowledge should be divided and subdivided so that individual institutions will be able to accept responsibility for attempting subject coverage in certain fields which by common agreement are allotted to them. Special collections should be built up, where needed, in areas of the country which do not have them at the present time. Duplication of specialization in certain areas should be lessened through exchange, long-term loans, sales, gifts, or consolidation of records. The distinction between working collections required for research up to the $\mathrm{Ph} . \mathrm{D}$. level and those necessary for research above that level should be recognized. Working collections in many institutions of necessity would duplicate each other, while those of 
a more special type should be located in appropriate depositories without the necessity of much duplication. The difference between data of primary interest because of rarity of items and records of importance due to content should be made clear. Through planned specialization, utilizing the adoption and carrying out of fair codes of collection and availability of material, institutions should be able to eliminate, to a considerable degree, competition for the same records. In this connection there should be widespread recognition that any institution possessing material for research should make it available for research purposes upon request, under proper restriction. This would involve special attention to the problem of procedure with respect to rare items. Microfilm, microprint, and other methods of copying will be of increasing importance both as a means of making materials available and at the same time protecting the rights of owners and custodians.

\section{Processing}

Reference libraries should find their situation improved by the end of the war because of advances in processing, particularly under the new leadership in the Library of Congress. It is suggested that a possible answer to the cataloging problem may be found by increasing the facilities of this division of the Library of Congress so that it will take care of most of the processing needs of American libraries, perhaps allocating on a cooperative basis a moderate amount of specialized work to institutions who would assume the responsibility for preparing information for catalog cards in their fields. All cards, however, should be printed and sold by the Library of Congress. It is further possible, in view of the varying needs of different types of libraries for detailed information, that several classes of cards might be issued, making it practicable for each library to order in accordance with its requirements. Because of the very considerable saving to processing divisions of individual institutions which might result from the adoption and carrying out of such a plan, it is probable that the price of catalog cards could be raised and also that certain institutions might be able to contribute, out of their savings, to the financial support of such a national, centralized cataloging division. Release of staff in libraries from concern with current materials would permit assignment to processing of older uncataloged items. To meet most of the cataloging needs of American libraries, the processing division would have to produce catalog cards quickly and accurately. This could be facilitated by improving the means whereby the books, or information about them and their authors, could be made available to the processing division in advance of publication release. There should be general agreement among reference libraries as to the types of material which require catalog cards and in how much detail the latter should be made for different purposes. It should be further understood what types of items could be controlled by simple number systems, checklists, guides, and indexes.

\section{Documentary Reproduction}

Availability of materials for research in reference libraries would be stimulated by planned programs of reproduction of important bodies of source material. Among requisite needs are a good quality of copying, careful editing, and reasonable cheapness of cost. Examples of large-scale 
enterprises are the reproduction of the British Sessional Papers from 1801-1900 now under way in microprint and the English copying program which is transferring to the Library of Congress, by means of microfilm, thousands of pages of source material in English depositories. In order to insure high technical standards and proper quality of product some central agency should be set up, such as the Council on Documentary Reproduction, suggested in the Memoranda on Library Cooperation, to serve as an advisory body with regard to copying programs. Also an agency of this kind could act as a clearing house with respect to new devices coming on the market and could institute laboratory experiments to improve techniques.

\section{Bibliography}

Reference libraries could render real service by aiding in a better coordination of bibliographical activities. Some central agency, such as a national institute of bibliography, should be created which would act as a clearing house of information and an advisory body. This institute might promote a few national projects such as the compilation of Lincoln and Washington bibliographies and also preparation of subject bibliographies based on the entries in the American Imprints Inventory. Individual institutions should assume the responsibility for assembling lists of existing materials about certain notable Americans. The example set by the University of Virginia Library with regard to Thomas Jefferson should be emulated by other institutions.

\section{Union Catalogs}

Planned specialization in the postwar period would be greatly stimulated by the revision and completion of the union cata$\log$ or guide to special collections which now exists in partial form in the Union Catalog Division of the Library of Congress. A necessary preliminary would involve more accurate definitions of the words "collection" and "specialization" than we have at the present time. Reference libraries could assist here by cooperating in assembling the desired information. These libraries should sponsor a union cata$\log$ of manuscripts based in the beginning on the more than one hundred guides to collections which have been issued by the Historical Records Survey. Such a catalog might be located in the Manuscript Division of the Library of Congress. Union catalogs of maps, illustrations, and museum objects will eventually be compiled and when completed will be found most useful. Preliminaries of these might be started as soon as a sufficient number of individual libraries have brought their own collections under catalog control.

The above prediction for American reference libraries in the postwar period alIudes briefly to certain of the activities in which institutions of that era will undoubtedly engage and, likewise, by indirection offers indication as to what sort of reference libraries they will be. It is obvious that library cooperation enters very largely into this picture. Institutions in this era, in order to acquire and make available materials for research to the greatest degree, must not only be able to operate independently but also more completely in conjunction with each other. In conclusion it is suggested that establishment of a permanent division of library cooperation would be of valuable aid in assisting reference libraries to render the fullest service to society. 